\title{
Expression of Her-2/neu in endometrial carcinoma and its relation with clinicopathological variables
}

\author{
*Hanaa O Badr Eldin and **Wafaa H A Helmy \\ *Departments of Obstetrics and **Gynecology and Pathology \\ Faculty of medicine, Al Azhar University.
}

\begin{abstract}
Objective and background: Her-2/neu tyrosine kinase has been implicated in the development and progression of several human cancers and is target for therapeutic intervention. Smaller studies suggest that Her-2/neu may be involved in the tumerogenesis of endometrial adenocarcinoma. The aim of this study was to evaluate Her-2/neu expression in endometrial carcinoma (EC) and its correlation with clinicopathological features in order to define the potential prognostic value of Her-2/neu overexpression in EC.

Patients and methods: Nineteen patients with stage I-IV EC were included in this study. Demographic, clinical and pathologic information was obtained and recorded. Her-2/neu expression was evaluated by immunohistochemistry (IHC) on paraffin embedded tissue sections with Her-2/neu antibody. Overexpression was defined as complete membrane staining in greater than $10 \%$ of cells.

Results: The positive rate of Her-2/neu in EC was $42.1 \%$. Her-2/neu was associated with surgical stage $(\mathrm{p}<0.01)$, lymph node involvement $(\mathrm{p}<0.05)$, lymph vascular space invasion $(\mathrm{p}$ $<0.05)$ and depth of myometrial invasion $(\mathrm{p}<0.01)$ but not associated with histological grade or the age of the patients $(\mathrm{p}>0.05)$.

Conclusion: Our study provides evidence of Her-2/neu overexpression in a considerable proportion of the patients with uterine adenocarcinoma, thus suggesting the opportunity for the possible use of anti-Her-2/neu therapy in this malignancy by selective inhibition of Her-2/neu. The use of Herceptin, a monoclonal antibody directed against Her-2/neu, for therapy of patients harboring Her-2/neu positive EC may be beneficial. Her-2/neu overexpression is related to most of the prognostic variables of EC and may be incorporated into the criteria for determination of tumor aggressiveness as a prognostic marker.
\end{abstract}

\section{Introduction}

Endometrial carcinoma (EC) is the most common malignant neoplasm of the genital tract and, despite its relative frequency; the molecular events that contribute to the development and progression of the lesion remain poorly understood (Iochin, 2005, Jemal et al., 2004 and Jemal et al., 2006). The normal human endometrium is characterized by hormonedependent variation during the menstrual cycle. This tightly controlled system is disturbed during endometrial hyperplasia and carcinomas and a series of changes initiate and promote progression toward malignant phenotype. These changes can be subdivided into discrete steps, involving activation of oncogenes or other proteins involved in tumor invasion and progression.
Immunohistochemical expression of different biomarkers such as oncogene Her$2 /$ neu has shown the contribution of these molecules to endometrial carcinogenesis in a hormone-dependent or independent manner as an early or late event. In addition these biomarkers seem to be correlated with different clinicopathologic variables, and therefore could be considered as indicators of the biological behavior of endometrial carcinomas (Iochin, 2005). However, these prognostic markers have been not fully identified (Slomovitz et al., 2004). A better understanding of the molecular basis of the biologic behavior of EC and the development of a novel, more specific, and more effective treatment modalities against it remain a high priority (Santin et al., 
2005a and Santin et al., 2005b). Smaller studies have suggested that oncogene Her$2 /$ neu overexpression may be present in a disproportionate number of EC and few documents have been reported about its relation with the clinicopathological variables (Slomovitz et al., 2004 and $\mathrm{Hu}$ et al., 2004).

Her-2/neu is an oncogene, located on chromosome 17, encoding a type 1 tyrosine kinase growth factor receptor (Olayioye et al., 2000). The human Her-2/neu (c-erbB-2) is a member of the epidermal growth factor receptor transmembrane receptor tyrosine kinase family (Akiyama et al., 1986 and Chazin et al., 1992). Her-2/neu (c-erbB-2) gene product expression plays an important role in coordinating the endometrial growth factor receptor signaling network (GrausPorta et al., 1997). In some cases, gene amplification may result in protein overexpression that constitutively activate tyrosine kinase causing increased mitogenic cell signaling and increased cell proliferation (Karunagaran et al., 1996 and Busse et al., 2000). Overexpression of Her$2 /$ neu has been found to play a role in cellular transformation, tumerogenesis and metastasis (Chazin et al., 1992). When Her$2 /$ neu is normally expressed, it leads to the combination of a few copies of Her-2/neu heterodimers and the Her-2/neu-mediated signaling is weak, resulting in a normal cell growth. In the presence of Her-2/neu amplification, there may be 50-100 genes per tumor cell leading to the expression of as many as 2,000,000 Her-2/neu proteins per cell in neoplastic tissue, instead of the 20,000-50,000 Her-2/neu proteins per cell in physiologic conditions (Busse et al., 2000). The final result is a ligandindependent activation of the Her-2/neu receptor, leading to an increased mitogenic cell signaling and proliferation, coupled with antiapoptotic and neoangiogenic effects (Odicino et al., 2007).

Her-2/neu is overexpressed in $25-30 \%$ of breast cancers and is associated with a shorter disease-free interval and over all survival (13, 15) (Seshardi et al., 1993 and Karunagaran et al., 1996). Her-2/neu expression has been studied in many other cancers and has been correlated with worse prognosis, a more aggressive biological behavior and may have a selective growth advantage over Her-2/neu-negative tumor cells (Hellstrom et al., 2001 and Andreson and Ahmad, 2002).

Since the transmembrane receptor encoded by the Her-2/neu cellular oncogene is amplified in several types of human carcinomas, it provides an attractive therapeutic target (Villella et al., 2006). Recently, a humanized MAB to Her-2/neu, Herceptin, has been reported to have significant therapeutic effects in patients with Her-2/neu positive breast carcinomas (Salmon et al., 2001) and its therapeutic efficacy has been inves-tigated in patients whose tumor exhibited strong plasmalemmal immunoreactivity for this protein (Agus et al., 2000) Targeting Her-2/neu may be beneficial for a select group of patient with EC. Few reports suggest the implem-entation of the same targeted therapy for EC patients exhibiting overexpression of Her-2/neu (Villella et al., 2006).

This study was designed to evaluate Her-2/neu protein overexpression in EC and its correlation with clinicopathological features in order to define its potential prognostic value in EC.

\section{Patients and methods}

Nineteen patients with stage I-IV EC were enrolled into this study between December 2001 and July 2006 who were diagnosed, treated and followed at the department of Obstetrics and Gynecology, Al Zahraa University Hospital. Demographic and clinical information, including age at time of diagnosis, weight, smoking history, other cancer history, family history, history of diabetes, and parity was obtained and recorded.

All patients underwent exploratory surgery, total hysterectomy, bilateral salpingooophorectomy and pelvic cytologic evaluation with pelvic lymphadenectomy. No patients received chemotherapy or radiotherapy before surgery. Pathological criteria evaluated included lymph vascular space invasion (LVSI), depth of myometrial invasion, grade of differentiation and lymph node status and complete pathologic information were recorded. Tumor staging was performed retrospectively according to the International Federation of Gynecology 
and Obstetrics (FIGO) in 1988. The standard preoperative preparation protocol including hematological and biochemical evaluation, a chest radiograph, an electrocardiogram, and abdominopelvic ultrasound were performed. Additional radiological studies including intravenous pyelography, computed tomography, magnetic resonance image, rectosigmoidscopy, or cystscopy were performed when clinically indicated.

Formalin-fixed, paraffin embedded tissue blocks concerning these cases were obtained and all hematoxylin \& eosinstained sections were reviewed, the quality of the material was checked, and the best sections from each specimen were selected. All microscopic slides were reviewed to confirm the histologic diagnosis. Patient's medical records and clinicopathologic characteristics were reviewed.

\section{Immunohistochemistry (IHC)}

Representative Formalin-Fixed, paraffin-embedded tissues were sectioned at Four micrometers for IHC. The steps of IHC are summarized as follows: All the slides were deparaffinized in xylene, rehydrated in decreasing concentrations of ethanol. The IHC staining for Her2-neu was performed by monoclonal ready to use. (LAB VISION, USA) using the universal $\mathrm{ABC}$, peroxidase kit (ultra-vision detection system, Anti-polyvalent, ready to use, LAB VISION, USA). All of the slides were treated with $0.3 \% \mathrm{H}_{2} \mathrm{O}_{2}$ in methanol for 10 min to block endogenous peroxidase activity, then the slides were washed in buffer, The sections were heated in citrate buffer solution $(0.01 \mathrm{~mol} / \mathrm{l}, \mathrm{pH}=6)$ in a microwave oven, three times for $10 \mathrm{~min}$ for epitope retrieval, then allowed to cool at room temperature for $20 \mathrm{~min}$. Sections were then incubated in Ultra V Block for $5 \mathrm{~min}$ at room temperature to block nonspecific background staining. Primary antibody was applied and incubated overnight at room temperature, slides were rinsed in buffer. Secondary antibody and avidin-biotin peroxidase complex $(\mathrm{ABC})$ reagent were added consecutively for 10 and $20 \mathrm{~min}$ at room temperature. DAB was applied as chromogen for $10 \mathrm{~min}$. Slides were counterstained with Mayer's hematoxylin for 5-10 min. Her-2/neu- expressing breast cancer was used as positive control. Negative controls were obtained by omitting the primary antibody. The pattern of staining was recorded and slides were analyzed for degree of Her-2/neu positivity.

According to Slomovitz et al. (Slomovitz et al., 2004) Her-2/neu intensity of IHC staining was scored as follows: negative (0) with no staining is observed; incomplete membranous staining or complete membranous staining in less than $10 \%$ of the tumor cells $(+1)$; moderate intensity, complete membranous staining in more than $10 \%$ of the tumor cells $(2+)$; or strong staining intensity, complete membrane staining is observed in more than $10 \%$ of the tumor cells $(3+)$. In this study, specimens with $2+$ or $3+$ staining were considered positive for antibody overexpression.

\section{Results}

\section{Clinicopathological findings}

Among 19 patients with endometrial adenocarcinoma, 12 were stage I-II and 7 cases were stage III-IV. Regarding the grade of differentiation of the studied specimens, 13 were grade 2 and 6 were grade 3. Lymph vascular space invasion was positive in 11/19 cases, whereas, lymph node metastases were reported in $7 / 19$ cases. Myometrial invasion $<50 \%$ was reported in $9 / 19$ cases, while myometrial invasion $\geq 50 \%$ was found in $10 / 19$. Regarding the age of the patients, 6 cases were $<60$ years old and the remaining were $\geq 60$ years.

\section{Immunohistochemistry findings}

Immunohistochemistry findings were demonstrated in table (1) and figures (2-4). Moderate to strong membranous expression of Her-2/neu protein by IHC was noted in $8 / 19(42.1 \%)$ cases; 3 specimens demonstrated moderate $(2+)$ staining and 5 cases expressed strong staining (3+) (Fig 2 \& 3)). The striking majority (4 out of 5 ) of the $3+$ cases demonstrated strong membrane staining uniformly distributed among all areas of the tumor. Heterogeneity in the staining patterns was found in $1 / 5$ cases of strong staining and $2 / 3$ specimens scored as $2+$ by IHC. In all other specimens, the staining was negative and/or mild (Fig 4) 
and therefore, these cases were all scored in the 0 to $1+$ categories (Table 1 ).

The correlation between Her-2/neu expression and various clinicopathologic variables:

The relations between Her-2/neu expression and various clinicopathologic variables of EC are listed in Table (2). Patients with disease limited to the uterus (stag I-II) were compared to those with extrauterine tumor spread (stage III-IV) regarding Her-2/neu expression. Statistically significant relation was reported between Her-2/neu expression and FIGO stage where $16.7 \%$ of patients in stage I-II demonstrated Her-2/neu expression, while $85.7 \%$ of patients with stage III-IV expressed Her-2/neu ( $\mathrm{p}<0.01$ ).
Regarding myometrial invasion, Her-2/neu expression was reported in $1 / 9$ with $<50 \%$ mymetrial invasion and in $7 / 10$ cases with $\geq 50 \%$ myometrial invasion, the difference was significant $(\mathrm{P}<0.01)$. According to grade of differentiation, no significant difference was reported in Her-2/neu expression between grade 2 and grade 3 ( $>0.5$ ). Furthermore, patients with lymph node metastases demonstrated significantly higher rates of Her-2/neu expression as compared to patients without lymph node metastases $(71.4 \%$ vs $25 \%, \mathrm{p}<0.05)$. Significant correlation was reported also between Her-2/neu expression and LVSI $(12.5 \%$ vs $63.6 \% \mathrm{p}<0.05)$. No statistically significant relation between Her-2/neu overexpression and the age of the patients could be detected.

Table (1): Prevalence of Her-2/neu expression by IHC in EC

\begin{tabular}{|c|c|}
\hline IHC score & $\begin{array}{c}\text { No.(\%) of cases } \\
(\mathbf{N}=19)\end{array}$ \\
\hline 0 & $6(31.6 \%)$ \\
$1+$ & $5(26.3 \%)$ \\
$2+$ & $3(15.8 \%)$ \\
$3+$ & $5(26.3 \%)$ \\
\hline
\end{tabular}

Table (2): Correlation between clinicopathological variables and Her-2/neu overexpression by IHC in EC

\begin{tabular}{|c|c|c|c|c|c|}
\hline Variables & Total & $\begin{array}{c}\text { Her-2/neu+ } \\
\text { N (\%) }\end{array}$ & $\begin{array}{c}\text { Her-2/neu- } \\
\text { n }(\%)\end{array}$ & $\mathbf{X}^{2}$ & $\mathbf{P}$ \\
\hline $\begin{array}{l}\text { LN } \\
\text {-ve } \\
+v e\end{array}$ & $\begin{array}{c}12 \\
7\end{array}$ & $\begin{array}{c}3(25) \\
5(71.4)\end{array}$ & $\begin{array}{c}9(75) \\
2(28.6)\end{array}$ & 3.91 & $<0.05$ \\
\hline $\begin{array}{l}\text { LVSI } \\
\text {-ve } \\
+ \text { ve } \\
\end{array}$ & $\begin{array}{c}8 \\
11 \\
\end{array}$ & $\begin{array}{l}1(12.5) \\
7(63.6)\end{array}$ & $\begin{array}{l}7(87.5) \\
4(36 . .4) \\
\end{array}$ & 4.96 & $<0.05$ \\
\hline $\begin{array}{l}\text { MI } \\
<50 \% \\
\geq \mathbf{5 0 \%}\end{array}$ & $\begin{array}{c}9 \\
10\end{array}$ & $\begin{array}{c}1(11.1) \\
7(70)\end{array}$ & $\begin{array}{c}8(88.9) \\
3(30)\end{array}$ & 6.74 & $<0.01$ \\
\hline $\begin{array}{l}\text { Grade } \\
2 \\
3\end{array}$ & $\begin{array}{c}13 \\
6\end{array}$ & $\begin{array}{l}4(30.8) \\
4(66.7)\end{array}$ & $\begin{array}{l}9(69.2) \\
2(33.3)\end{array}$ & 2.17 & $>0.05$ \\
\hline $\begin{array}{l}\text { Stage } \\
\text { I-II } \\
\text { III-IV }\end{array}$ & $\begin{array}{c}12 \\
7 \\
\end{array}$ & $\begin{array}{l}2(16.7) \\
6(85.7) \\
\end{array}$ & $\begin{array}{c}10(83.3) \\
1(14.3) \\
\end{array}$ & 8.64 & $<0.01$ \\
\hline $\begin{array}{l}\text { Age } \\
<60 \mathrm{yrs} \\
\geq 60 \mathrm{yrs}\end{array}$ & $\begin{array}{c}6 \\
13 \\
\end{array}$ & $\begin{array}{l}2(33.3) \\
6(46.2)\end{array}$ & $\begin{array}{l}4(66.7) \\
7(53.8) \\
\end{array}$ & 0.278 & $>0.05$ \\
\hline
\end{tabular}

LN= lumph node involvement

LVSI= lymph vascular space invasion

$M I=$ myometrial invasion 


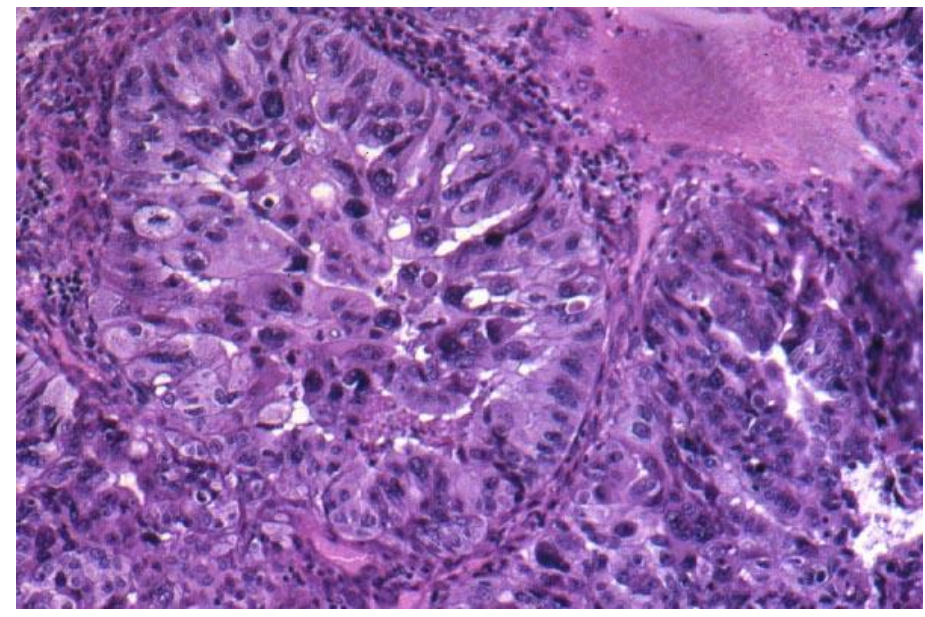

Fig 1: Section showed endometrial adenocarcinoma grade III. There was marked pleomorphism and mitotic figures. The glands were backed to each other and the stroma was scanty. (H \& E X 200)

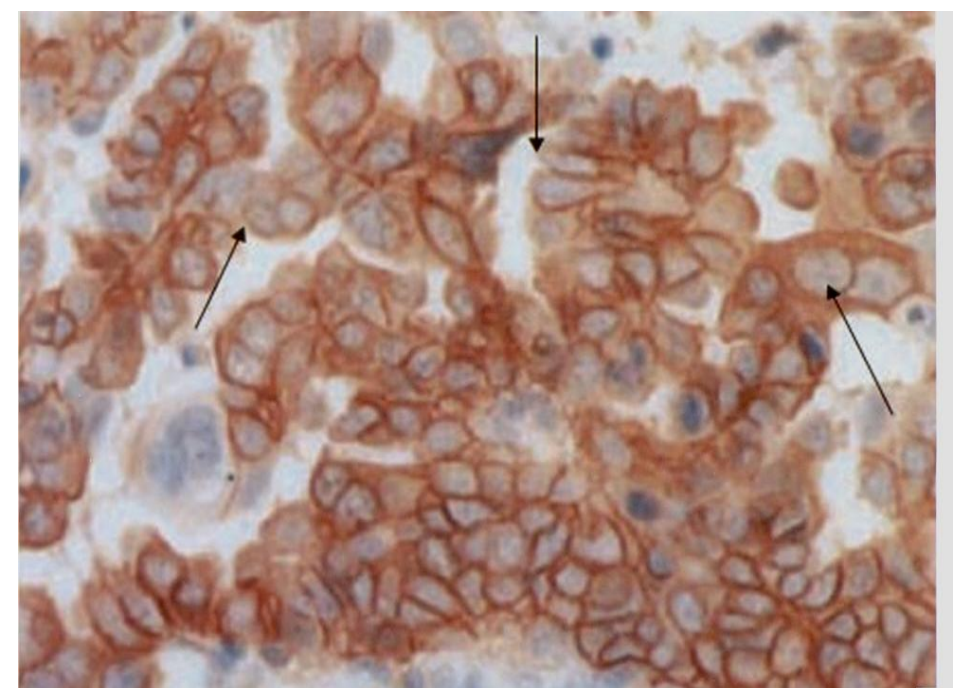

Fig 2: Section in moderately differentiated endometrial carcinoma showed moderate score expression of Her2-neu. There was incomplete marking of the cell membrane (Arrows) less than more than $10 \%$ of cells. The case was stage III and associated with lymph node metastasis ( Immunoperoxidase DAB X 400) 

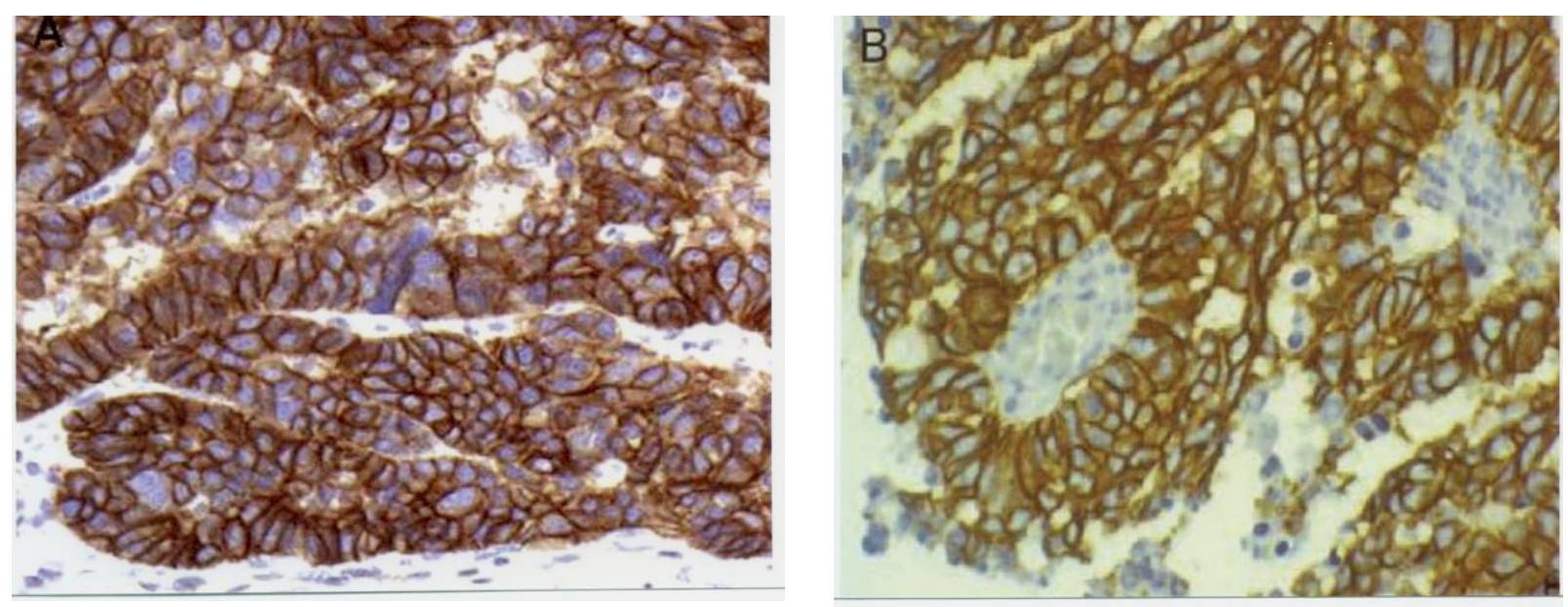

Fig 3: Sections in endometrial carcinoma grade III demonstrated strong expression of Her2neu with complete marking of the cell membrane in most of the section. A) A case with stage III and B) was stage IV. Both cases were positive for lymph node metastasis (Immunoperoxidase DAB X 200)

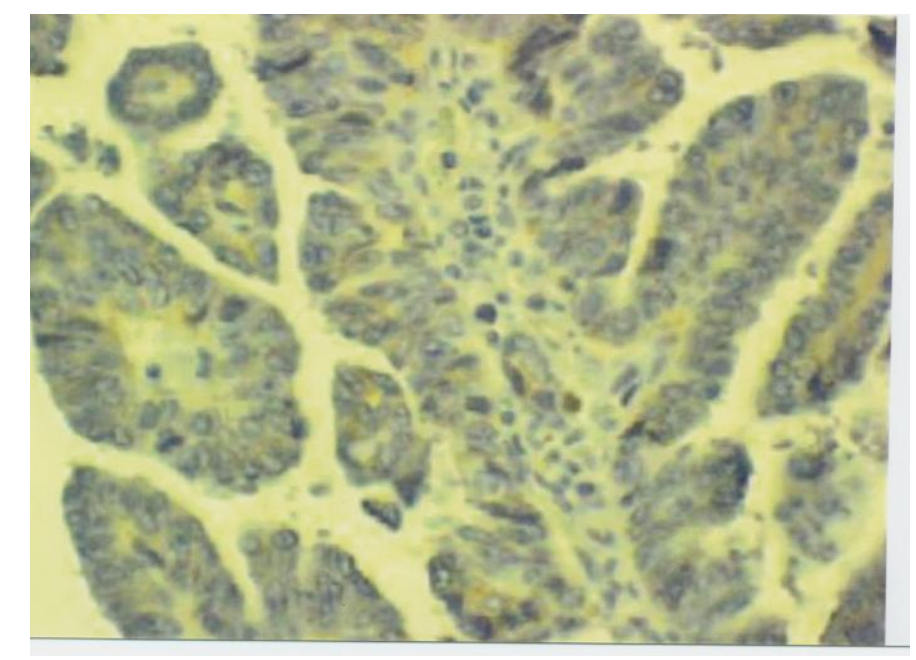

Fig 4: Well differentiated endometrial carcinoma showed negative expression of Her2-neu. The case was stage I and negative for lymph node metastasis (Immunoperoxidase DAB X 200)

\section{Discussion}

In the last few years, several clinical studies have shown that Her-2/neu gene amplification and/or protein overexpression represents the prototype of stable molecular abnormalties endowed with well-characterized functional consequences that are detectable in several solid tumors. Her$2 /$ neu has been implicated in the development and progression of several human cancers and is target for therapeutic intervention. Smaller studies suggest that Her-2/neu may be involved in the tumerigenesis of EC. Prognostic and therapeutic implication of Her-2/neu overexpression and amplification in this tumor continue to evolve (Slomovitz et al., 2004, Hu et al., 2004, Villella et al., 2006 and Livasy , et al., 2006).

In the literature, the reported rates of Her-2/neu overexpression and amplification 
in EC range from 17\% to $80 \%$. In this study we demonstrated a higher rate of Her-2/neu protein overexpression in EC (42.1\%) when compared with the results of others ( $\mathrm{Hu}$ et al., 2004, Slomovitz , et al., 2004, Livasy et al., 2006 and Odicino et al., 2007). Other studies reported that Her-2/neu expression was positive in $55.2 \%$ (Cherchi et al., 2001), $71 \%$ (Villella et al., 2006) and 80\% (Santin et al., 2002) which were higher than that reported in the current study suggesting that oncogene Her-2/neu plays a role in the carcinogenesis of considerable proportion of EC.

The wide range of expression is probably due to the different detection methods used and the inherent variability in IHC. Protein targets may differ among the IHC methods used. Moreover, one problem is the difficulty with the definition of Her$2 /$ neu overexpression. The criteria for Her$2 /$ neu positivity require complete membranous staining in greater than $10 \%$ of the tumor cells. In some of the previous studies this criteria was not clearly defined. Some studies did not distinguishing complete from partial staining. Partial or incomplete membranous staining likely accounts for the higher rates of Her-2/neu positivity (Slomovitz et al., 2004). In addition, counting cases showing 2+ immunoreactivity as positive for Her-2/neu overexpression, may account for some of the variations in the overexpression rates reported (Santin et al., 2005). The difference in the histological types of EC may also explain the variations in the reported rates of Her-2/neu positivity in various studies. The positive rate of Her$2 /$ neu in endometroid adenocarcinoma was $23.2 \%$ in the study of $\mathrm{Hu}$ et al. (2004), while Santin et al. (2005) found that $62 \%$ of uterine papillary serous carcinoma (USPC) expresses moderate to strong (2+ to $3+$ ) Her-2/neu stain and Santin et al. (2002) reported that 8 out of 10 cases with USPC stained heavily for Her-2/neu (2+to 3+). In cases with uterine carcinosarcoma, Raspollini et al. (2006) demonstrated Her2/neu expression in $32.1 \%$ while Sawada et al. (2003) reported Her-2/neu overexpression in 9 of 16 (56\%). Moreover, tissue preparation, fixation, and storage techniques may vary and yield inconsistent results. Inherent intraobserver variability in
IHC may also accounts for the large differences in reported positivity among publications which has been demonstrated in studies with multiple pathologists interpreting the results of IHC (Hoang et al., 2000).

Her-2/neu is correlated with clinical variables that result in a poorer prognosis as high tumor grading and staging, deeper myometrial invasion, and higher percentage of disease progression and relapse (Cianciulli et al., 2003). Similarly, Cherechi et al. (2001) demonstrated a positive correlation between Her-2/neu expression and grading, myometrial invasion and FIGO stage which indicate a more malignant tumor phenotype. Coronado et al. (2001) examined different histologic subtypes of endometrial cancer and reported that Her-2/neu expression was more frequent in tumors with advancedstage disease, nonendometroid subtypes, deep myometrial invasion and high grade histology. Her-2/neu overexpression associated with a higher stage and lymph node positivity and poorer overall survival (Slomovitz et al., 2004). Moreover, $\mathrm{Hu}$ et al. (2004) reported that, Her-2/neu expression was associated with surgical pathologic stage and depth of myometrial invasion in EC and may predict poor prognosis, but was not associated with histologic grade. In the clinical setting, high levels of Her-2/neu in tumor tissue have been associated with shorter survival, resistance to antiestrogens, and chemotherapeutic drugs, and resistance to tumor necrosis factor alpha, activated macrophages, and lymphokine-activated killer cells (Nicholson, et al., 1990, Ioannides et al., 1992 and Santin et al., 2002).

In agreement with the results of these studies, we demonstrated a significant relationship between Her-2/neu overexpression and FIGO stage of the tumor, myometrial invasion, LVSI and lymph node metastases, indicating that Her-2/neu is related to most of the prognostic factors of EC. These findings supporting the notion that Her-2/neu overexpression may be a major prognostic factor and Her-2/neu IHC could be incorporated as a prognostic variable in patients with EC. These results suggest also that Her-2/neu may represent a 
crucial molecular-genetic prognostic factor responsible for the highly aggressive biologic behavior of EC harboring Her$2 /$ neu overexpression.

There have been numerous studies in breast cancer showing that first-line treatment with trastuzmab, a humanized anti-Her-2/neu antibody, in combination with chemotherapy increases response rates, time to progression, quality of life, and overall survival in the subset of women whose breast tumors demonstrate $3+$ Her2/neu overexpression by IHC (Mass et al., 2000, Salmon, et al., 2001 and Vogel et al., 2002). In analogy to breast cancer patients harboring disease with proven amplification or strong Her-2/neu overexpression, EC patients with overexpression of Her-2/neu may potentially benefit from Herceptin therapy. Herceptin has a binding region of 529-625 amino acids long that targets Her$2 /$ neu overexpression and causes down regulation of, blocks Her-2/neu cleavage, and inhibit angiogenesis (Albanell et al., 2003).

Santin et al. (2002) postulated that Herceptin might be a novel and attractive therapeutic strategy in patients with EC either for the prevention of recurrence after surgical treatment or for the treatment of metastases. Consistent with this view, the high sensitivity of USPC cells to natural killer-mediated, antibody-dependent cytotoxicity triggered by anti-Her-2/neu-specific antibody in vitro, as well as clinical responses in vivo, which has recently been reported with the use of Herceptin in patients with UPSC (Villella et al., 2003). In the study of Villella et al. (2006), select patients with strong positivity responded to treatment with trastuzumab, introducing an additional treatment option for patients with EC. Therefore, Herceptin may represent a novel, potentially highly effective therapy for patients with EC harboring Her-2/neu overexpression. However, the authors concluded that the clinical value of single agent Herceptin was limited by the low frequency of Her-2/neu expression (Bookman et al., 2003). The value of Herceptin therapy should be investigated in clinical trials to evaluate its efficacy for the treatment of patients harboring Her-2/neu positive endometrial carcinoma.
In conclusion, our study provides evidence of Her-2/neu overexpression in a considerable proportion of the patients with uterine adenocarcinoma, thus suggesting the opportunity for the possible use of antiHer-2/neu therapy in this malignancy by selective inhibition of Her-2/neu by monoclonal antibodies. This approach has already been successfully applied in breast cancer patients using humanized monoclonal antibody that blocks the extracellular domains of the Her-2/neu receptor (trastuzumab) (Salmon et al., 2001). Her-2/neu expression is related to most of clinicopathologic and prognostic variables of EC and may be incorporated into the criteria for determination of tumor aggressiveness as a prognostic marker.

\section{References}

1. Agus DB, Bunn PA, Jr Franklin W, Garzia M, and Ozols RF (2000): Her$2 /$ neu as therapeutic target in non small cell lung cancer, prostate cancer and ovarian cancer. Semin Oncol; 27: 53.

2. Akiyama $\mathbf{T}$, Sudo $\mathbf{C}$ and Ogawara $\mathbf{H}$ (1986): The product of c-erbB-2 gene: A 185-kilodalton glycoprotein with tyrosine kinase activity. Science; 232:1644.

3. Albanell J, Codony J, Rovira A, Mellado $B$ and Gascon $P$ (2003): Mechanism of action of anti-Her-2/neu monoclonal antibodies: scientific update on trastuzumab and 2c4. adv Exp Med Biol; 532: 253.

4. Andreson NG and Ahmad T (2002): ErbB-2 receptor tyrosine kinase inhibitors as therapeutic agents. Font Biosci; 7:1926.

5. Bookman MA, Darcy KM, ClarkePearson D, Boothby RA and Horowitz IR (2003): Evaluation of monoclonal humanized anti-Her-2/neu antibody, trastuzumab, in patients with recurrent or refractory ovarian or primary peritoneal carcinoma with overexpression of Her2/neu: a phase II trial of the Gynecologic Oncology Group. J Clin Oncol; 21:238.

6. Busse D, Doughty RS and Arteaga CL (2000). Her-2/neu (erbB-2) and the cell cycle. Semin Oncol; 27(6 suppl.11):3-8, discussion 92.

7. Chazin VR, Kaledo $M$ and Miller AD (1992): Transformation mediated by the human Her-2/neu gene independent of the epidermal growth factor receptor. Oncogene; 7: 1859. 
8. Cherchi PL, Marras V, Capobianco G, Ambrosini G, Pig md, Fadda $\mathbf{N}$ and Dessole S (2001): Prognostic value of p53, c-erbB-2 and MIB-1 in endometrial carcinoma. Eur J Gynecol Oncol;22: 451.

9. Cianciulli AM, Guadagni $\mathbf{F}$ and Mazano R (2003). Her-2/neu oncogene amplification and chromosome 17 aneusomy in endometrial carcinoma: correlation with oncoprotien expression and conventional pathological parameters. J Exp Clin Cancer Res; 22:256.

10. Coronado OJ, Vidart JA and LopezAsenjo JA (2001): P53 overexpression predicts endometrial carcinoma recurrence better than Her-2/neu overexpression. Eur J Obstet Gynecol Reprod Biol; 98: 103.

11. Graus-Porta D, Beerli RR, Daly MJ and Hynes NE 1997. ErbB 2, the preferred heterodimerization partner of all ErbB-2 receptors, is a mediator of lateral signaling. EMBO J; 16: 1647.

12. Hellstrom I, Goodman G, Pullman J and Hellstrom KE (2001): Overexpression of Her-2/neu in ovarian carcinomas. Cancer Res; 61:2420.

13. Hoang MP, Sahin AA, Ordonez NG and Sneige N (2000): Her-2/neu protein overexpression and interobserver reproducibility in invasive breast carcinoma. Am J Clin Pathol; 113: 852.

14. Hu WF, Liu MQ and Zhao Q (2004): Expression of P53, P63, and C-erbB-2 in endometroid adenocarcinoma and their clinicopathological significance. $\mathrm{Ai}$ Zheng; 23:1021.

15. Ioannides CG, Ioannides MG and O'Brian CA (1992): T cell recognition of oncogene products: a new strategy for immunotherapy. Mol Carcingo; 6: 77.

16. Iochin E. (2005): Immunohistochemical tumor markers in endometrial carcinoma. Eur J Gynecol Oncol;26: 363.

17. Jemal A, Tiwari RC, Murray T, Ghafoor A, Samuels $A$ and Ward $E$ (2004): Cancer statistics. CA Cancer J Clin; 54: 8.

18. Jemal A, Siegel $R$ and Ward $E$ (2006): Cancer statistics. CA Cancer J Clin; 56:106.

19. Karunagaran D, Tzahar E, Beeri R,R Chin X, Graus-Porta D, Ratzkin BJ, Hynes NF and Yarden Y (1996): ErbB-2 is a common auxiliary subunit of NDF receotors : implication for breast cancer. EMBO J; 15:254.

20. Livasy CA, Reading FC, Moore DT, Boggess JF, and Lininger RA (2006): EGFR expression and her-2/neu overexpression/amplification in endometrial carcin-osarcoma. Gynecologic Oncology; 100:101.

21. Mass R, Sanders $C$ and Kasian $C$ (2000): The concordance between the clinical trials assay and fluorescence in situ hybridization in the Herceptin pivotal trials. Proc Am Soc Clin Oncol; 19: 75a (abstract 291).

22. Nicholson S, Wright C, Sainsbury JR, Halcrow P, Kelly P, Angus B, Farndon JR and Harris AL (1990): Epidermal growth factor as a marker for poor prognosis in node-negative breast cancer patients: neu and tamoxifen failure. J Steroids Biochem Mol Biol; 37:811.

23. Odicino FE, Bignotti E, Rossi E, Pasintti B, Tassi RA, Donzelli C, Falchetti M, Fontana P, Grigolato PG and Pecorelli $\mathbf{S}$ (2007) Her-2/neu overexpression and amplification in uterine serous papillary carcinoma: comparative analysis of immunohistochemistry, real-time reverse transcription-polymerase chain reaction, and fluorescence in situ hybridization. Int J Gynecol Cancer; 19:1.

24. Olayioye MA, Neve RM, Lane HA and Hynes NE (2000): The ErbB-2 signaling network: receptor heterodimerization in the development and cancer. EMBO J; 19:3159.

25. Raspollini MR, Susini T, Amunni G, Paglierani M, Casttiglione F, Garbini F, Carriero C, Scarselli G and Taddei GL (2006): Expression and amplification of her-2/neu oncogene in uterine carcinisarcomas: a marker for potential molecularly targeted treatment? Int J Gynecol Cancer; 16:416.

26. Salmon DL, Leyland-Jones B, Shak S, Fuchs H, Paton V and Bajamonde A (2001): Use of chemotherapy plus a monoclonal antibody against Her-2/neu for metastatic breast cancer that overexpresses Her-2/neu. N Engl J Med; 344: 783.

27. Santin AD, Bellone S, Gokden $M$, Plameiri M, Dunn D, Agha J, Roman JJ, Hutchins L, Pecorelli S, and O'Brien T (2002): Over expression of Her-2/neu in uterine serous papillary cancer. Clinical Cancer Research; 8:1271.

28. Santin AD, Bellone S, Stedum S, Bushen W, Bushen W, De Las Casas LE, Korourian S, Tian E, Roman JJ, Burnett $A$ and Pecorelli S (2005a): Determination of her-2/neu in uterine serous papillary carcinoma: comparative analysis of immunohis-tochemistry and fluorescence in situ hybridization. Gynecologic Oncology; 98: 24. 
29. Santin AD, Bellone S, Stedum S, Bushen W, Palmieri M, Siegel ER, De Las Casas LE and Roman JJ (2005b): Amplification of c-erbB-2 oncogene, a major prognostic indicator in uterine serous papillary carcinoma. Cancer; 104: 1391.

30. Sawada $M$, Tsuda $H$ and Kimura $M$ (2003): Different expression patterns of KIT, EGFR and Her-2/neu (c-erbB2) oncoprotiens between epithelial and mesenchymal components in uterine carcinosarcoma. Cancer Sci; 94:986.

31. Seshardi R, Firgaira FA, Horsfall DJ, McCaul K, Setlur V and Ktchen P ( 1993): Clinical significance of Her-2/neu oncogene amplification in primary breast cancer. J Clin Oncol; 11:1936.

32. Slomovitz BM, Broaddus RR, Burke NS, Soliman PT, Wu W, Sun CC, Munsell MF, Gershenson DM and Lu
KH (2004): Her-2/neu overexpression and amplification in uterine papillary serous carcinoma. J Clin Oncol; 22:3126.

33. Villella JA, Cohen S, Smith DH, Hibshoosh $H$ and Hershmans D (2003): Her-2/neu overexpression in uterine papillary serous cancers (abstract). Proc Am Soc Clin Oncol; 465:1870.

34. Villella JA, Cohen S, Smith DH, Hibshoosh H and Hershmans D (2006): Her-2/neu overexpression in uterine papillary serous cancers and its possible therapeutic implications. Int J Gynecol Cancer; 16:1902.

35. Vogel CL, Cobliegh MA, and Tripathy D (2002): Efficacy and safety of trastuzumab as a single agent in first-line treatment of Her-2/neu overexpressing metastatic breast cancer. J Clin Oncol; 20: 719. 


\section{ظهور بروتين هير 2 نيو فى سرطان بطانة الرحم و علاقته بالعوامل

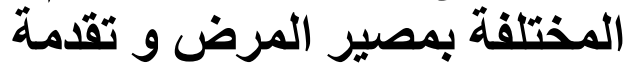

$$
\begin{aligned}
& \text { * هناء عمر بلدر الدين ، **وفاء حلمى عباس حلمى }
\end{aligned}
$$

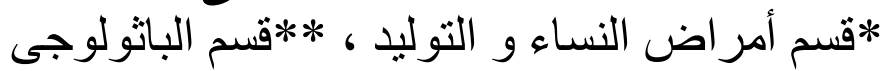

$$
\begin{aligned}
& \text { كلية الطب - جامعة الاز هر لأند }
\end{aligned}
$$

الهـف من البحث:

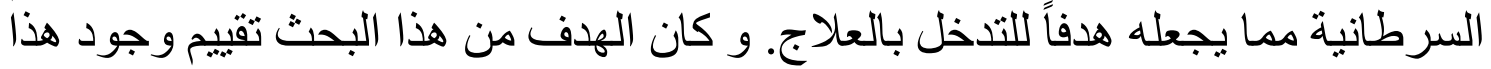

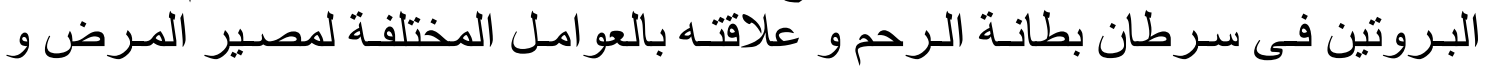

أخذت عينه من هذه الور الدر اسة لدر على تسعة هذا البروتين بو سيدة بعد تشخيص كمياء الانسجة. ورم بطانة الرحم بهن و

النتائج: لقد ظهر هذا البروتين فى 42.1 \% من السيدات اللاتحى يعانين من سرطان

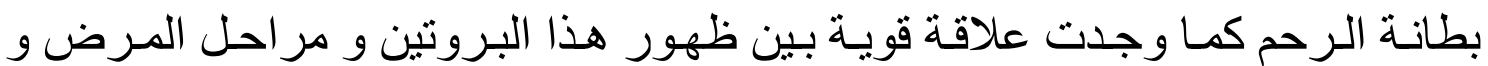

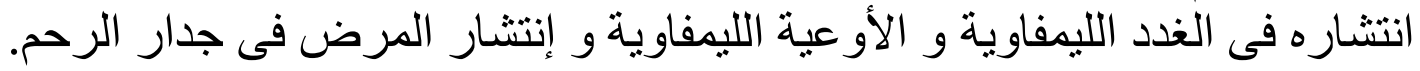

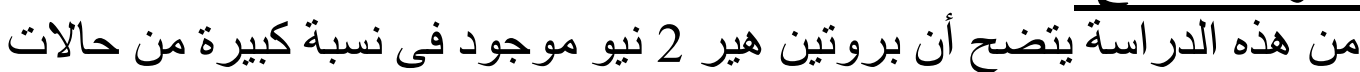
الخلاصة و الاستنتشاج:

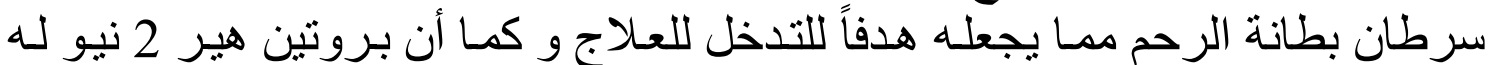

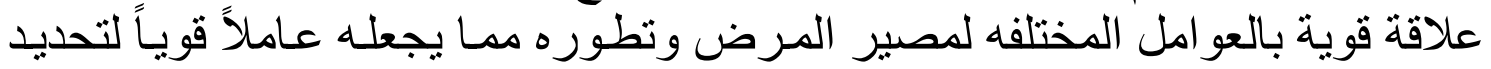

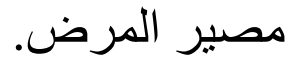

